\title{
Effects of soil types and forms of arsenical pesticide on rice growth and development
}

\author{
${ }^{1}$ S. Quazi; ${ }^{2}$ R. Datta; ${ }^{3 *}$ D. Sarkar \\ ${ }^{1}$ Environmental geochemistry Laboratory, University of Texas at San Antonio, San Antonio, Texas, USA \\ ${ }^{2}$ Department of Biological Sciences, Michigan Technological University, Houghton, Michigan, USA \\ ${ }^{3}$ Department of Earth and Environmental Studies, Montclair State University, Montclair, New Jersey, USA \\ Received 7 December 2010; $\quad$ revised 11 January 2011; accepted 21 April 2011; available online 1 June 2011
}

\begin{abstract}
For decades, repeated and widespread use of arsenical pesticides has significantly contributed to arsenic contamination in soils. Residues from the overuse of these arsenicals may result in phytotoxicity to crops, which will depend on soil types, plant species and the toxicity of arsenical pesticides. A greenhouse column study was conducted to evaluate the effect of two pesticides, i.e. one organic (dimethylarsinic acid) and one inorganic (sodium arsenate), on the vegetative response of rice as a function of soil properties. Four soils with varying arsenic retention capabilities at two different pesticide amendment rates (675 and $1500 \mathrm{mg} / \mathrm{kg}$ ) representing the worst case scenarios in superfund sites were used. Results showed that arsenic availability to rice was mainly influenced by soil physicochemical properties. The soil with the lowest arsenic retention capacity had the highest arsenic concentration in the leachate as well as in the plant tissue. In contrast, for soils with higher arsenic retention capacity, higher concentrations of arsenic were found in the surface soil which resulted in the inhibition of plant growth. There was no significant difference between labile arsenic / plant-available arsenic irrespective of the form of arsenical pesticide used. Plant growth parameters such as biomass, shoot height, root length decreased with increased arsenic concentrations in all soils. A significant negative correlation $(\mathrm{P}<0.05)$ was observed between the phytoavailable arsenic and plant growth response. Interestingly, the form of arsenical pesticide used did not impact arsenic uptake or shoot growth but significantly impacted root growth.
\end{abstract}

Keywords: Dimethylarsinic acid; Oryza sativa; Phytoavailability; Phytotoxicity; Sodium arsenate

\section{INTRODUCTION}

In the United States, Arsenic (As) was primarily used in the preparation of insecticides and herbicides (Murphy and Aucott, 1998) to control various insect pests in cotton fields during 1930s and 1940s (Baker et al., 1986). During the 1970s, agricultural products accounted for approximately $81 \%$ of the total As used (Adriano, 2001) resulting in the contamination of agricultural soils, leading to reduced productivity (Marin et al., 1993a). This resulted in the replacement of inorganic arsenical pesticides with organic herbicides (methanearsonic acid and its salts, and cacodylic acid and its salts) (Woolson, 1983), which were applied at lower rates (Marin et al., 1993a). In the late 1980s and early 1990s, the US Environmental Protection Agency (EPA) banned the use of many

凶*Corresponding Author Email: sarkard@mail.montclair.edu Tel.: +1 973655 7273/ Fax: +19736556810 inorganic As-based pesticides (Datta and Sarkar, 2005), which resulted in a $40 \%$ decrease in As agricultural applications (Adriano, 2001). However, past use of arsenical pesticides has resulted in highly contaminated agricultural soils in several areas in the U.S. (Belluck et al., 2003). Organic arsenicals such as Dimethylarsinic acid (DMA) $\left(\left(\mathrm{CH}_{3}\right)_{2} \mathrm{AsO}_{2} \mathrm{Na}_{3} 3 \mathrm{H}_{2} \mathrm{O}\right)$, considered to be less toxic (Pongratz, 1998), have been used as herbicides on agricultural lands, orchards and golf courses (Sarkar et al., 2005) until the recent phasing out of the methylated arsenical compounds except for monosodium methyl arsenate (MSMA) from the market (US EPA, 2009). Due to their low application rate and low toxicity, these organoarsenicals have received less attention than their inorganic counterparts (Marin et al., 1993a). Arsenic toxicity differs considerably between its organic and inorganic chemical forms (Cullen and 
Reimar, 1989; Turpeinen et al., 1999; Garcia-Manyes et al., 2002; Feng et al., 2009; Urík et al., 2009). Being a nonessential component for plants (Marin et al., 1993b), As interferes with metabolic processes, inhibiting plant growth and leading to death at high concentrations (Reed and Sturgis, 1936; Schweizer, 1967; Baker et al., 1986; Marin et al., 1992). Toxicity depends on the stage of growth or the biological process (germination, seedling survivability, vegetative growth) of the plant along with the concentration and type of toxicant (Liu et al., 2005). Plants are more sensitive to toxicants during the early growth period due to their undeveloped defense mechanism, which makes germination and seedling growth an important consideration for toxicity assessment (Liu et al., 2005). Toxicity symptoms resulting from exposure to high concentration of inorganic As include decreased root and shoot lengths (Carbonella-Barrachina et al., 1995; Kang et al., 1996; Abedin and Meharg, 2002a; Abedin et al., 2002b); inhibition of seed germination (Abedin and Meharg, 2002a); wilting and necrosis of leaf blades (Odanaka et al., 1987; Frans et al., 1988 ); reduction in leaf area and photosynthesis; and lower fruit and grain yield. A comparison of toxicity studies of different arsenical compounds applied to roots at a relatively low rate showed that Dimethylarsenic acid (DMA) was the least toxic (Marin et al., 1992; Sachs and Michael, 1971). Information on the toxic effects of organic arsenicals on plant species, except the ones being treated with the pesticide, is scarce. Sckerl and Frans (1969) and Marin et al. (1993a) suggested that organic arsenicals inhibit photosynthesis and block protein synthesis or other biosysnthetic pathways.

In general, crops do not readily take up As (Maclean and Langille, 1981; Xu and Thronton, 1985). As species differ in solubility and mobility, therefore differing in their availability to the plant. The factors that affect the accumulation of As by plants include As concentration (NAS, 1977), plant species (Liebig, 1966; Walsh and Keeney, 1975), and soil properties. Properties such as $\mathrm{pH}$, clay content (Dickens and Hiltbold, 1967; Von Endt et al., 1968; Johnson and Hiltbold, 1969) and redox potential (Marin et al., 1993b) affect As speciation and solubility, thereby determining As phytoavailability and phytotoxicity (Marin et al., 1993b). Woolson et al. (1973) reported that As phytotoxicity on rice depended on the type of soil and was highest in loamy sand and lowest on silty clay loam. According to Sheppard (1992), As is five times more toxic in sands and loams than in clay soils and the available form is an important factor regarding phytotoxicity (Abedin and Meharg, 2002a). Studies have shown that the order of As availability to rice (Oryza sativa L.) was as follows: DMA $<$ As (V) $<$ MMA $<$ As (III) (Marin et al., 1992). However, As availability to marsh grass (Spartina alterniflora L.) grown hydroponically followed the trend: DMA $<<$ MMA $<$ As(V) < As(III) (Carbonell et al., 1998). Reports have suggested DMA to be the least toxic, and most studies with DMA have been carried hydroponically at concentrations ranging from $0.2 \mathrm{mg}$ As/L to 1.6 $\mathrm{mg}$ As/L. In the case of inorganic arsenicals, most studies have reported As phytotoxicity on rice grown on soils with concentrations ranging from 0.5 -150 mg of As/kg soil (Sheppard, 1992).

Repeated application of arsenical pesticides on agricultural crops has resulted in soil sterility or unproductiveness (Walsh and Keeney, 1975). Soil residues may pose problems to sensitive crops where rotation is practiced (Woolson, 1983). Problems can also arise during replantation of orchards to agronomic use or transformation of agricultural lands to suburban developments, which may cause risk to humans through the consumption of homegrown vegetables or via contact with the highly contaminated soil. It is important to understand the relationship between the soil As forms, concentrations and plant-availability of As with respect to soil physico-chemical properties.

The Arsenic concentrations selected for this greenhouse study represented the worst case scenarios resulting from repeated application of arsenical pesticides. Former orchard sites in North Carolina and in Washington State have been reported to contain 389 and $2353 \mathrm{mg} / \mathrm{kg}$ respectively (NRC, 1977; Walsh et al., 1977). For this greenhouse study, rice was used as a test crop, since rice is a staple food crop in South East Asia and also grown popularly in other parts of the world. In Bangladesh and certain states in India such as West Bengal, rice intake is the major exposure route ( $\mathrm{Li}$ et al., 2009). Sometimes rice is cultivated in agricultural lands that have accumulated elevated levels of As that are much higher than the baseline concentration (Zhu et al., 2008). Paddy soils in Bangladesh have been found to contain high As concentration (Saha and Ali, 2007); as high as $50 \mathrm{mg} /$ $\mathrm{kg}$ (Alam and Sattar, 2000) and $87 \mathrm{mg} / \mathrm{kg}$ (Ullah, 1998) due to the use of As contaminated water for irrigation. Liao et al. (2005) reported agricultural soils that were 
contaminated with $1217 \mathrm{mg} / \mathrm{kg}$ of As, due to industrial activities. As concentration in the rice grain from Lioa et al. (2005) study was high (0.5 to $7.5 \mathrm{mg} / \mathrm{kg})$. A pot study by Jahiruddin et al. (2004) reported that soil As concentraton of $5-50 \mathrm{mg} / \mathrm{kg}$ resulted in poor yield of rice. Similarly reduced yield of As was observed in a greenhouse study by Abedin et al. (2002c) due to the use of elevated As containing water. The current study is a part of a greenhouse experiment that attempts to elucidate As bioaccessibility in inorganic and organic arsenical pesticide-amended soils. The current study aims to evaluate the effect of the two pesticides on the vegetative response of rice as a function of soil properties. This study has two objectives: 1) to evaluate the effect of the source of As: sodium arsenate $\left(\mathrm{Na}_{2} \mathrm{HAsO}_{4} .7 \mathrm{H}_{2} \mathrm{O}\right)$ and DMA on the plant-available form of As as a function of soil properties; 2) to determine whether the source of As in soil affects plant growth and As uptake in rice. This study was conducted in the Environmental Geochemistry Laboratory and the Greenhouse facility of the University of Texas, San Antonio from 2004-2007.

\section{MATERIALS AND METHODS}

Soil sampling, preparation and charecterization

Four surface soils $(0-12 \mathrm{~cm})$ were used for the greenhouse study. The Immokalee series was collected from the Southwest Florida Research and Education Center in Immokalee, Florida. The Millhopper series was collected from the University of Florida campus at Gainesville, Florida. The Pahokee Muck series was collected from the Everglades Research and Education Center in Bellglade, Florida and the Orelia soil was collected from Corpus Christi, Texas. Soil samples were air dried, passed through a 2-mm sieve, and characterized for various soil properties. Soil pH, electrical conductivity, particle size, water content and cationexchange capacity were measured using standard protocols (Sparks, 1996). Organic matter was measured using the loss-on-ignition method (Sparks, 1996). Plantavailable $\mathrm{P}$ was extracted via the Mehlich III solution (Mehlich, 1984). Oxalate-extractable Fe and Al were obtained using Tamm's reagent (Sparks, 1996). Total recoverable $\mathrm{Ca}, \mathrm{Mg}, \mathrm{Fe}, \mathrm{Al}, \mathrm{P}$, and As was obtained by soil digestion according to US EPA method 3050B (US EPA, 1996). Phosphorus was measured colorimetrically by a UV/Visible light spectrophotometer using the molybdate-ascorbic acid method (Watanabe and Olsen,
1965). Calcium, Mg, and Al were analyzed using the Flame atomic absorption spectrometry (FAAS) and As was analyzed by Graphite furnace atomic absorption spectrometry (GFAAS).

\section{Greenhouse study Soil ammendments and plant growth}

The soils were spiked with two pesticides: Sodium arsenate and DMA at two rates (i.e. 675 and $1500 \mathrm{mg}$ As/kg soil). Polyvinyl chloride (PVC) columns (13" tall x 6" internal diameter) were used in this greenhouse study to grow rice plants. The bottom 7" of the columns was filled with white sand with no As retention capacity. Pesticide-amended soil was packed in the top 6" of the PVC column. Each column was provided with a reservoir compartment at the bottom to hold the excess leachate, which had a hole fitted with nalgene tubing to collect the leachate. The columns were arranged in a randomized block design and were rotated periodically to account for variances in temperature and sunlight within the greenhouse. The total number of PVC columns used for the treatments were 48 ( 4 soils $\times 2$ pesticides $\times 2$ rates $\times 3$ replicates) and 12 controls (4 soils $\mathrm{x} 3$ replicates). Leaching was induced after 2 weeks of pesticide application. Approximately $1 \mathrm{~L}$ of de-ionized water was added to each of the column to induce leaching. Leachate water was analyzed for soluble As using the GFAAS. Seeds were sown directly on the soils. Prior to sowing, the seeds were surface-sterilized in 3 $\% \mathrm{H}_{2} \mathrm{O}_{2}$ and then rinsed with distilled water. The number of germinated seeds was counted $4 \mathrm{~d}$ after initiation of germination and the results were expressed as a percentage. Seeds were considered germinated when the plumule had extended to more than $2 \mathrm{~mm}$ from the junction. Rice seedlings were harvested from the columns after 6 months of soilpesticide equilibration. Plants were watered regularly and Miracle-Gro® All Purpose Plant Food was used to fertilize the plants. Soils were watered regularly to maintain their moisture content (70 \% of the water holding capacity). Shoot and root heights were measured during harvesting. Shoot height was measured from the stem base to the tip of the longest leaf and root length was measured from the root-shoot junction to the tip of the longest root. Soils were collected from the surface layer at three different time periods : 1) Immediately after spiking (time-0); 2) After leaching, i.e. two weeks after soil pesticide 
equilibration (time-mid); and 3) After six months of soilpesticide equilibration (time-final). The soils were then assessed for soil-As forms.

\section{Sequential extraction procedure}

The sequential extraction scheme developed by Chungao and Zihui (1988) with a few modifications (Datta and Sarkar, 2004) was employed to identify the operationally defined forms of As: water soluble; exchangeable As ( $\mathrm{NH}_{4} \mathrm{Cl}$ extractable); amorphous $\mathrm{Fe} /$ Al-bound ( $\mathrm{NaOH}$ extractable); $\mathrm{Ca} / \mathrm{Mg}$-bound As $\left(\mathrm{H}_{2} \mathrm{SO}_{4}\right.$ extractable As); organic/sulfides-bound As $\left(\mathrm{H}_{2} \mathrm{O}_{2}\right.$ extractable); and residual $\mathrm{As}$ ( $\mathrm{HNO}_{3}$ extractable). Extracts were filtered and analyzed for soluble As using GFAAS. For this study, data on the labile (soluble + exchangeable) forms of As alone has been presented, because this fraction governs the potentially plantavailable As.

\section{Statistical analysis}

JMP IN 5.1 (Sall et al., 2005) statistical software for Windows was used for statistical analyses. Data were analyzed with a three-way ANOVA at $\alpha=0.05$ significance level. A correlation matrix was constructed from Pearson's coefficients to relate labile As form for both pesticides at time -mid with seedling germination, root / shoot height, plant biomass and As uptake by plants.

\section{RESULTS AND DISCUSSION}

\section{Soil properties}

Physico-chemical characterization data for the soils used in this study are summarized in Table 1 . The four soils used in this study were selected based on their potential differences with respect to As reactivity, as a result of their distinct physico-chemical properties. Immokalee soil is acid sand with low $\mathrm{Fe} / \mathrm{Al}, \mathrm{Ca} / \mathrm{Mg}$, and $\mathrm{P}$ contents. Millhopper, Pahokee Muck, and Orelia, conversely, had high levels of extractable Fe/Al oxides, as well as high $\mathrm{Ca} / \mathrm{Mg}$ and $\mathrm{P}$ content. Immokalee was used as a control in this study to compare the effects of high concentrations of $\mathrm{Fe}, \mathrm{Al}, \mathrm{P}, \mathrm{Ca}, \mathrm{Mg}$ and organic matter, in Millhopper, Pahokee Muck and Orelia on their As retention capacity. Both Immokalee and Millhopper soils were sandy (99.7 \% and $96 \%$, respectively) (Table 1 ), but the lack of positively charged adsorptive surfaces (e.g. amorphous Fe/Al oxides) in Immokalee would result in lower As retention, thereby increasing the available As fraction (Pierce and Moore, 1980; Oscarson et al., 1981). Orelia soil had the lowest percentage of sand and the highest percentage of clay (22\%). Millhopper, and Pahokee Muck were acidic (pH varying between 4.0-4.5), while Orelia had an alkaline $\mathrm{pH}$ (7.5). The soils also varied in their salinity, with the lowest (59 $\mu \mathrm{S} / \mathrm{cm}$ ) for Immokalee and the highest (552 $\mu \mathrm{S} / \mathrm{cm})$ for Pahokee Muck. Pahokee Muck also had high organic matter content (85\%) in addition to the highest concentration of oxalate-extractable Fe/Al (1957 $\mathrm{mg} / \mathrm{kg}$ ) compared to the other three soils (Table 1). Total $\mathrm{Ca}$ and $\mathrm{Mg}$ content were highest in case of Pahokee Muck (40800 mg/kg). Major factors that control trace metal concentrations in soils include clay content, organic carbon content, $\mathrm{pH}$ and $\mathrm{Fe} / \mathrm{Al}$ content (Chen et al., 1999). Millhopper, Pahokee Muck and Orelia, therefore, would likely be able to retain higher concentrations of As compared to Immokalee, and

Table 1: General chemical properties of the four soils: Immokalee, Millhopper, Pahokee Muck and Orelia

\begin{tabular}{lrrrr}
\hline Soil properties & Immokalee & Millhopper & Pahokee Muck & \multicolumn{1}{c}{ Orelia } \\
\hline $\mathrm{pH}$ & $4.03 \pm 0.5$ & $4.62 \pm 0.40$ & $4.54 \pm 0.00$ & $7.48 \pm 0.10$ \\
$\mathrm{EC} *(\mu \mathrm{S} / \mathrm{cm})$ & $59 \pm 5.0$ & $145 \pm 8.00$ & $552 \pm 5.50$ & $203 \pm 1.00$ \\
$\mathrm{SOM}^{* *}(\%)$ & $2.32 \pm 0.2$ & $3.46 \pm 0.67$ & $85.25 \pm 0.13$ & $3.78 \pm 0.15$ \\
Sand $(\%)$ & $99 \pm 0.0$ & $96 \pm 0.00$ & $86 \pm 0.00$ & $63 \pm 0.00$ \\
Clay (\%) & $0.57 \pm 0.1$ & $1.62 \pm 0.30$ & $4.67 \pm 0.50$ & $21.91 \pm 0.60$ \\
Silt (\%) & $0.37 \pm 0.0$ & $0.78 \pm 0.00$ & $7.08 \pm 0.50$ & $9.56 \pm 3.10$ \\
Coarse silt (\%) & 0 & 0 & $1.79 \pm 0.10$ & $4.77 \pm 2.50$ \\
Fe + Al (mg/kg) & $41 \pm 5.5$ & $582 \pm 590$ & $1957 \pm 1630$ & $380 \pm 15.0$ \\
Oxalate & $100 \pm 25$ & $4739 \pm 974$ & $6812 \pm 1650$ & $6100 \pm 51.2$ \\
Total & & & & \\
P (mg/kg) & $9.35 \pm 1.8$ & $239 \pm 1.8$ & $48.62 \pm 2.20$ & $62 \pm 14.0$ \\
Mehlich & $208 \pm 6.0$ & $4845 \pm 204$ & $6812 \pm 580$ & $1700 \pm 68.0$ \\
Total & $1178 \pm 106$ & $3155 \pm 497$ & $40800 \pm 2346$ & $13100 \pm 1221$ \\
Ca+Mg (mg/kg) Total & & & \\
\hline
\end{tabular}

* EC = Electrical conductivity; ${ }^{*}$ SOM $=$ Soil organic matter 
thereby have lower amounts of the labile As fraction. However, given the high $\mathrm{P}$ content in Millhopper, As availability could be higher in this soil due to similar chemical properties of As and P, which are likely to compete for the same sorption sites.

\section{Changes in labile arsenic}

Availability, toxicity and mobility of As in soil-waterplant systems are largely determined by the speciation and distribution, or partitioning of As between the solution and soil matrix (Han et al., 2004). Table 3 shows the distribution of labile As (soluble + exchangeable As forms) at three different time periods: time-0 (immediately after spiking), time-mid (after leaching) and time-final (6 months after soil-pesticide equilibration). Differences in the labile form varied with the soil type, amendment rates and source of As, which were significantly influenced by their interactions based on the three-way ANOVA (Table 2).
For Immokalee amended with Sodium arsenate at 675 and $1500 \mathrm{mg} \mathrm{As} / \mathrm{kg}$, the labile form at time 0 was $608 \pm 14$ and $1242 \pm 33 \mathrm{mg}$ As/kgrespectively (Table $3)$. After leaching, however, the labile form significantly $(\mathrm{P}<0.05)$ decreased to 82.8 and $117 \mathrm{mg}$ As/kg (Table 3). Reportedly, Fe and $\mathrm{Al}$ are the primary solid phases that influence soil As solubility (Woolson et al., 1971a; Johnston and Barnard, 1979; Livesey and Huang, 1981). Arsenic is strongly adsorbed onto Fe and Al oxides (Jacobs et al., 1970), thereby rendering the mobility of As. Immokalee is acid sand with very low $\mathrm{Fe} / \mathrm{Al}$ oxyhydroxides, resulting in low As retention capacity.

Oxalate-extractable $\mathrm{Fe}+\mathrm{Al}$ concentration for Immokalee is only $41 \mathrm{mg} / \mathrm{kg}$ (Table 1 ). As a result, As leached from the surface soil to the leachate water, leading to a decrease in the total As concentration in the soil as well as the labile form. No significant difference was observed after 6 months for the lower

Table 2: Results of the three-way ANOVA and Student's t-test for the effects of soil types, As concentration and arsenic source on plant uptake, plant growth parameters (germination, plant height, plant biomass) and labile arsenic and total arsenic for all the soils used in the study

\begin{tabular}{|c|c|c|c|c|c|c|}
\hline \multirow[b]{2}{*}{ Source of variation } & \multirow[b]{2}{*}{$\begin{array}{l}\text { Plant As } \\
\text { (mg/kg) }\end{array}$} & \multicolumn{3}{|c|}{ Plant growth parameters } & \multicolumn{2}{|c|}{$\begin{array}{l}\text { Soil As } \\
\text { (mg/kg) }\end{array}$} \\
\hline & & Germination & Plant height & Plant biomass & Labile & Total \\
\hline & & $(\%)$ & $(\mathrm{mm})$ & (mg) & & \\
\hline \multicolumn{7}{|c|}{ Three-way ANOVA (F-values) } \\
\hline Soil type & $0.29 \mathrm{NS}^{*}$ & $8.50 * * *$ & $14.65 * * * *$ & $0.00 \mathrm{NS}$ & $64.38 * * * *$ & $4.70 * *$ \\
\hline As concentration & $31.65 * * * *$ & $65.56 * * * *$ & $1514 * * * *$ & 149. **** & $283 * * * *$ & $417 * * * *$ \\
\hline As source & $46.66 * * * *$ & $266 * * * *$ & $6417 * * * *$ & $1637 * * * *$ & $429 * * * *$ & $1255 * * * *$ \\
\hline Soil type $\mathrm{x}$ As concentration & $3.67 * *$ & $29.28 * * * *$ & $169.36 * * * *$ & $5.17 * * *$ & $21.71 * * * *$ & $126.38 * * * *$ \\
\hline Soil type $\mathrm{x}$ As source & $9.60 * * *$ & $63.28 * * * *$ & $4.28 *$ & $4.59 * *$ & $17.40 * * * *$ & $18.34 * * * *$ \\
\hline $\begin{array}{l}\text { As concentration } \mathrm{x} \text { As source } \\
\text { Soil type } \mathrm{x} \text { As concentration }\end{array}$ & $12.42 * * * *$ & $32.49 * * * *$ & $573 * * * *$ & $41.47 * * * *$ & $75.75 * * * *$ & $130 * * * *$ \\
\hline$\times$ As source & $2.10 \mathrm{NS}$ & $7.50 * * * *$ & $69.99 * * * *$ & $4.88 * * * *$ & $23.10 * * * *$ & $44.75 * * * *$ \\
\hline \multicolumn{7}{|c|}{ Student's t-test (Treatment means) } \\
\hline $\begin{array}{l}\text { Soil type } \\
\text { Immokalee } \\
\text { Millhopper } \\
\text { Pahokee muck } \\
\text { Orelia }\end{array}$ & $\begin{array}{r}112 \mathrm{~A} \\
27.22 \mathrm{BC} \\
35.51 \mathrm{~B} \\
8.75 \mathrm{C}\end{array}$ & $\begin{array}{l}85.93 \mathrm{~A} \\
80.93 \mathrm{~B} \\
80.12 \mathrm{~B} \\
58.39 \mathrm{C}\end{array}$ & $\begin{array}{r}115 \mathrm{~A} \\
80.29 \mathrm{C} \\
100 \mathrm{~B} \\
29.36 \mathrm{D}\end{array}$ & $\begin{array}{r}16.75 \mathrm{~A} \\
11.85 \mathrm{C} \\
13.85 \mathrm{~B} \\
6.78 \mathrm{D}\end{array}$ & $\begin{array}{r}51.43 \mathrm{C} \\
186 \mathrm{~B} \\
156 \mathrm{~B} \\
492 \mathrm{~A}\end{array}$ & $\begin{array}{r}95.89 \mathrm{D} \\
464 \mathrm{C} \\
528 \mathrm{~B} \\
826 \mathrm{~A}\end{array}$ \\
\hline $\begin{array}{l}\text { As concentration }(\mathrm{mg} / \mathrm{kg}) \\
0 \\
675 \\
1500\end{array}$ & $\begin{array}{r}0.00 \mathrm{C} \\
96.19 \mathrm{~A} \\
42.01 \mathrm{~B}\end{array}$ & $\begin{array}{l}93.33 \mathrm{~A} \\
83.35 \mathrm{~B} \\
52.34 \mathrm{C}\end{array}$ & $\begin{array}{r}157 \mathrm{~A} \\
56.71 \mathrm{~B} \\
30.31 \mathrm{C}\end{array}$ & $\begin{array}{c}25.98 \mathrm{~A} \\
7.76 \mathrm{~B} \\
3.18 \mathrm{C}\end{array}$ & $\begin{array}{l}0.00 \mathrm{C} \\
269 \mathrm{~B} \\
395 \mathrm{~A}\end{array}$ & $\begin{array}{r}0.00 \mathrm{C} \\
541 \mathrm{~B} \\
895 \mathrm{~A}\end{array}$ \\
\hline $\begin{array}{l}\text { As source } \\
\text { Sodium arsenate } \\
\text { DMA }\end{array}$ & $\begin{array}{l}43.87 \mathrm{~A} \\
48.26 \mathrm{~A}\end{array}$ & $\begin{array}{l}74.14 \mathrm{~B} \\
78.54 \mathrm{~A}\end{array}$ & $\begin{array}{l}79.70 \mathrm{~B} \\
83.40 \mathrm{~A}\end{array}$ & $\begin{array}{l}12.31 \mathrm{~A} \\
12.30 \mathrm{~A}\end{array}$ & $\begin{array}{r}266 \mathrm{~A} \\
176 \mathrm{~B} \\
\end{array}$ & $\begin{array}{l}494 \mathrm{~A} \\
462 \mathrm{~B}\end{array}$ \\
\hline
\end{tabular}

*NS: Not significant; $\mathrm{F}$ ratio $(\mathrm{P}<0.05) ; * *, * * *$ and $* * * *$ mean significant at $\mathrm{P}<0.05,0.01$ and 0.001 respectively. Values followed by the same letter, within the same source of variation, are not significantly different at $\mathrm{P}<0.05$ based on Student's t-test 
concentration, but for the higher concentration (1500 $\mathrm{mg} \mathrm{As} / \mathrm{kg}$ ), the labile form reduced further to $42.3 \mathrm{mg}$ As/kg which indicates that equilibration time for soils with higher As concentrations are longer. In case of Millhopper, significant decrease in the labile As was observed for both the rates. Although the oxalateextractable $\mathrm{Fe} / \mathrm{Al}$ was high, rendering As unavailable, the high $\mathrm{P}$ content might have increased the mobility and availability of As to $402 \mathrm{mg}$ As/ $\mathrm{kg}$ at the higher rate (Table 3). Studies have reported that because As and $\mathrm{P}$ have similar chemical properties, they often compete for similar sorption sites, resulting in increased As mobility and availability (Manning and Goldberg, 1996). After six months of soil-pesticide equilibration, however, the labile form decreased significantly ( $\mathrm{P}$ $<0.05$ ). This can be attributed to As becoming recalcitrant with time after application (Onken and Adriano, 1997). For Pahokee Muck, having the highest oxalate-extractable Al + Fe concentrations (1957 \pm 163 $\mathrm{mg} / \mathrm{kg}$ ), the amount of As in labile form was the lowest compared to the other three soils at time 0 (Table 3). After leaching, the labile As concentration decreased further to $<200 \mathrm{mg} \mathrm{As} / \mathrm{kg}$, though no significant difference $(\mathrm{P}>0.05)$ was present in the labile As at the three different time periods for the lower treatment rate. For the higher treatment rate, a significant decrease in As concentration was observed after leaching. In the case of Orelia, the labile form was high at all time periods, with no significant difference at the lower rate after time-mid (Table 3). At the higher amendment rate, leaching significantly reduced the labile form and the concentration was much higher compared to the other three soils (Immokalee, Millhopper and Pahokee Muck) (Table 3). Similar changes in labile As were observed for soils amended with DMA. A tracer study using ${ }^{14} \mathrm{C}$ labeled cacodylate suggested that cacodylic acid behaves like phosphate (Woolson and Kearney, 1973) and is thus expected to behave like inorganic soil As (Wauchope, 1975). Therefore, soil properties that affect sorption, thereby the mobility and availability of inorganic As, would also affect DMA in a similar fashion. A significant difference was observed in the labile As at time 0 and time mid for Immokalee at both treatment rates, a finding similar to the sodium arsenatetreated soils (Table 3). In an 8-week study of cacodylic acid applied to three soils, Woolson and Kearney (1973) observed that water-soluble cacodylic acid decreased with a concomitant increase in the less soluble aluminum-bound fraction. Difference in the distribution was due to the greater clay content and available Fe and Al content (Woolsonand Kearney, 1973). A similar decrease was observed in the labile form with a concomitant increase in the other geochemical forms: $\mathrm{Fe} / \mathrm{Al}$ bound, $\mathrm{Ca} / \mathrm{Mg}$ bound, organic bound (data not shown). A significant difference was observed in labile forms at time 0 and mid for all the soils. With the exception of Millhopper, no significant difference $(P>0.05)$ was reported for the soils after 6 months. This observation was similar to that found for Millhopper soil amended with sodium arsenate (Table 3).

Table 3: Biomass, shoot, root length and arsenic uptake in rice grown in Immokalee, Millhopper, Pahokee Muck and Orelia. Labile arsenic (soluble + exchangeable) forms for all the soils are also shown at three different time periods

\begin{tabular}{|c|c|c|c|c|c|c|c|}
\hline \multicolumn{2}{|c|}{ Soil treatment } & \multicolumn{2}{|c|}{$\begin{array}{c}\text { Biomass } \\
\text { (gm) }\end{array}$} & \multicolumn{2}{|c|}{$\begin{array}{l}\text { Shoot length } \\
\text { (mm) }\end{array}$} & \multicolumn{2}{|c|}{$\begin{array}{l}\text { Root length } \\
\text { (mm) }\end{array}$} \\
\hline Soil type & $\begin{array}{c}\text { As } \\
\text { concentration } \\
(\mathrm{mg} / \mathrm{kg})\end{array}$ & $\begin{array}{l}\text { Sodium } \\
\text { arsenate }\end{array}$ & DMA & $\begin{array}{l}\text { Sodium } \\
\text { arsenate }\end{array}$ & DMA & $\begin{array}{l}\text { Sodium } \\
\text { arsenate }\end{array}$ & DMA \\
\hline Immokalee & $\begin{array}{r}0 \\
675 \\
1500\end{array}$ & $\begin{array}{c}25.5 \pm 3.4 \mathrm{~A} \\
15.3 \pm 0.53 \mathrm{~B} \\
10.2 \pm 1.07 \mathrm{C}\end{array}$ & $\begin{array}{r}25.5 \pm 3.4 \mathrm{~A} \\
14.5 \pm 0.5 \mathrm{~B} \\
9.5 \pm 1.0 \mathrm{C}\end{array}$ & $\begin{array}{c}124 \pm 4.1 \mathrm{~A} \\
77.3 \pm 2.0 \mathrm{~B} \\
46.2 \pm 3.1 \mathrm{C}\end{array}$ & $\begin{array}{r}124 \pm 4.1 \mathrm{~A} \\
74.2 \pm 1.9 \mathrm{~B} \\
43.4 \pm 2.9 \mathrm{C}\end{array}$ & $\begin{array}{c}40.5 \pm 2.7 \mathrm{~A} \\
24.3 \pm 0.9 \mathrm{~B} \\
14.2 \pm 0.7 \mathrm{~B}\end{array}$ & $\begin{array}{l}40.5 \pm 2.7 \mathrm{~A} \\
23.4 \pm 0.9 \mathrm{~B} \\
13.4 \pm 0.6 \mathrm{C}\end{array}$ \\
\hline Millhopper & $\begin{array}{r}0 \\
675 \\
1500\end{array}$ & $\begin{array}{r}27.2 \pm 1.28 \mathrm{~A} \\
10.2 \pm 0.88 \mathrm{~B} \\
0 \pm 0 \mathrm{D}\end{array}$ & $\begin{array}{r}27.2 \pm 1.28 \mathrm{~A} \\
9.2 \pm 0.8 \mathrm{~B} \\
2.6 \pm 0.9 \mathrm{C}\end{array}$ & $\begin{array}{r}109 \pm 5.2 \mathrm{~A} \\
84.5 \pm 1.5 \mathrm{~B} \\
0 \pm 0 \mathrm{D}\end{array}$ & $\begin{array}{r}109 \pm 5.2 \mathrm{~A} \\
76.8 \pm 1.4 \mathrm{~B} \\
51.1 \pm 9.83 \mathrm{C}\end{array}$ & $\begin{array}{r}30.7 \pm 2.2 \mathrm{~A} \\
23.0 \pm 3.2 \mathrm{~B} \\
0 \pm 0 \mathrm{D}\end{array}$ & $\begin{array}{r}30.7 \pm 2.2 \mathrm{~A} \\
20.9 \pm 2.9 \mathrm{~B} \\
11.4 \pm 2.8 \mathrm{C}\end{array}$ \\
\hline Pahokee Muck & $\begin{array}{r}0 \\
675 \\
1500\end{array}$ & $\begin{array}{r}32.5 \pm 2.07 \mathrm{~A} \\
4.9 \pm 1.65 \mathrm{~B} \\
3.3 \pm 0.15 \mathrm{C}\end{array}$ & $\begin{array}{r}32.5 \pm 2.07 \mathrm{~A} \\
4.8 \pm 1.7 \mathrm{~B} \\
3.2 \pm 0.1 \mathrm{C}\end{array}$ & $\begin{array}{c}186 \pm 2.1 \mathrm{~A} \\
31.7 \pm 1.2 \mathrm{~B} \\
13.0 \pm 0.2 \mathrm{C}\end{array}$ & $\begin{array}{c}186 \pm 2.1 \mathrm{~A} \\
31.2 \pm 1.1 \mathrm{~B} \\
12.8 \pm 0.2 \mathrm{C}\end{array}$ & $\begin{array}{c}58.5 \pm 1.1 \mathrm{~A} \\
8.8 \pm 1.3 \mathrm{~B} \\
2.9 \pm 0.5 \mathrm{D}\end{array}$ & $\begin{array}{r}58.5 \pm 1.1 \mathrm{~A} \\
8.7 \pm 1.3 \mathrm{C} \\
2.9 \pm 0.5 \mathrm{D}\end{array}$ \\
\hline Orelia & $\begin{array}{r}0 \\
675 \\
1500\end{array}$ & $\begin{array}{r}18.7 \pm 1.73 \mathrm{~A} \\
0 \pm 0 \mathrm{~B} \\
0 \pm 0 \mathrm{C}\end{array}$ & $\begin{array}{r}18.7 \pm 1.73 \mathrm{~A} \\
0 \pm 0 \mathrm{~B} \\
0 \pm 0 \mathrm{C}\end{array}$ & $\begin{array}{r}34.5 \pm 1.2 \mathrm{~A} \\
0 \pm 0 \mathrm{~B} \\
0 \pm 0 \mathrm{C}\end{array}$ & $\begin{array}{r}34.5 \pm 1.2 \mathrm{~A} \\
0 \pm 0 \mathrm{~B} \\
0 \pm 0 \mathrm{C}\end{array}$ & $\begin{array}{r}15.6 \pm 2.6 \mathrm{~A} \\
0 \pm 0 \mathrm{~B} \\
0 \pm 0 \mathrm{C}\end{array}$ & $\begin{array}{r}15.6 \pm 2.6 \mathrm{~A} \\
0 \pm 0 \mathrm{~B} \\
0 \pm 0 \mathrm{C}\end{array}$ \\
\hline
\end{tabular}


Int. J. Environ. Sci. Tech., 8 (3), 445-460, Summer 2011

Table 3 (Continiued): Biomass, shoot, root length and arsenic uptake in rice grown in Immokalee, Millhopper, Pahokee Muck and Orelia. Labile arsenic (Soluble + Exchangeable) forms for all the soils are also shown at three different time periods

\begin{tabular}{|c|c|c|c|c|c|c|c|c|c|}
\hline \multirow{2}{*}{\multicolumn{2}{|c|}{ Soil treatment }} & \multicolumn{6}{|c|}{$\begin{array}{l}\text { Labile As (soluble + exchangeable) } \\
\text { (mg/kg) }\end{array}$} & \multirow{2}{*}{\multicolumn{2}{|c|}{$\begin{array}{l}\text { As uptake } \\
\text { ( mg/kg dry wt) }\end{array}$}} \\
\hline & & \multicolumn{3}{|c|}{ Sodium arsenate } & \multicolumn{3}{|c|}{ DMA } & & \\
\hline $\begin{array}{l}\text { Soil } \\
\text { type }\end{array}$ & $\begin{array}{c}\text { As } \\
\text { concentration } \\
(\mathrm{mg} / \mathrm{kg})\end{array}$ & Time-zero & Time-mid & Time-final & Time-zero & Time-mid & Time-final & $\begin{array}{l}\text { Sodium } \\
\text { arsenate }\end{array}$ & DMA \\
\hline \multirow{3}{*}{ Immokalee } & 0 & $0.01 \pm 0.0 \mathrm{~F}$ & $0.02 \pm 0.2 \mathrm{~F}$ & $0.08 \pm 0.1 \mathrm{~F}$ & $0.01 \pm 0.01 \mathrm{~F}$ & $0.02 \pm 0.2 \mathrm{~F}$ & $0.08 \pm 0.14 \mathrm{~F}$ & $0 \pm 0 \mathrm{C}$ & $0 \pm 0 \mathrm{C}$ \\
\hline & 675 & $608 \pm 14.0 \mathrm{C}$ & $82.8 \pm 5.5 \mathrm{DE}$ & $28.3 \pm 1.4 \mathrm{EF}$ & $650 \pm 53.2 \mathrm{C}$ & $29.8 \pm 2.3 \mathrm{EF}$ & $26.1 \pm 2.5 \mathrm{EF}$ & $243 \pm 108$ A & $231 \pm 03 \mathrm{~A}$ \\
\hline & 1500 & $1242 \pm 32.8 B$ & $117 \pm 3.6 \mathrm{D}$ & $42.3 \pm 18.9 \mathrm{EF}$ & $1676 \pm 130.1 \mathrm{~A}$ & $40.2 \pm 9.3 \mathrm{EF}$ & $29.7 \pm 13.2 \mathrm{EF}$ & $143 \pm 52.1 B$ & $133 \pm 48.5 \mathrm{~B}$ \\
\hline \multirow{3}{*}{ Millhopper } & 0 & $0.08 \pm 0.1 \mathrm{~K}$ & $0.09 \pm 0.2 \mathrm{~K}$ & $0.08 \pm 0.0 \mathrm{~K}$ & $0.08 \pm 0.1 \mathrm{~K}$ & $0.09 \pm 0.2 \mathrm{~K}$ & $0.08 \pm 0.0 \mathrm{~K}$ & $0 \pm 0 \mathrm{C}$ & $0 \pm 0 \mathrm{C}$ \\
\hline & 675 & $449 \pm 12.5 \mathrm{D}$ & $155 \pm 12.7 \mathrm{I}$ & $107 \pm 21.4 \mathrm{~J}$ & $513 \pm 51.4 \mathrm{C}$ & 211 38.7GH & $132 \pm 8.9 \mathrm{I}$ & $67.7 \pm 3.7 \mathrm{~B}$ & $60.9 \pm 3.4 \mathrm{~B}$ \\
\hline & 1500 & $1129 \pm 32.5 \mathrm{~A}$ & $401 \pm 12.3 \mathrm{E}$ & $193 \pm 20.6 \mathrm{HI}$ & $1041 \pm 26.9 \mathrm{~B}$ & $306 \pm 36.1 F$ & $247 \pm 18.9 G$ & $0 \pm 0 \mathrm{C}$ & $83.7 \pm 33.2 \mathrm{~A}$ \\
\hline \multirow{3}{*}{$\begin{array}{l}\text { Pahokee } \\
\text { Muck }\end{array}$} & 0 & $0.21 \pm 0.0 \mathrm{~F}$ & $0.16 \pm 0.0 \mathrm{~F}$ & $0.14 \pm 0.0 \mathrm{~F}$ & $0.21 \pm 0.0 \mathrm{~F}$ & $0.16 \pm 0.0 \mathrm{~F}$ & $0.14 \pm 0.0 \mathrm{~F}$ & $0 \pm 0 \mathrm{C}$ & $0 \pm 0 \mathrm{C}$ \\
\hline & 675 & $245 \pm 100 \mathrm{CD}$ & $169 \pm 11.5 \mathrm{DE}$ & $103 \pm 12.5 \mathrm{E}$ & $312 \pm 52.3 \mathrm{C}$ & $132 \pm 8.9 \mathrm{E}$ & $108 \pm 13.3 \mathrm{E}$ & $18.8 \pm 2.9 \mathrm{~B}$ & $18.3 \pm 2.9 \mathrm{~B}$ \\
\hline & 1500 & $574 \pm 31.9 B$ & $262 \pm 2.81 \mathrm{C}$ & $239 \pm 24.2 \mathrm{CD}$ & $823 \pm 47.9 \mathrm{~A}$ & $290 \pm 63.7 C$ & $227 \pm 19.7 \mathrm{CD}$ & $52.5 \pm 4.4 \mathrm{~A}$ & $50.9 \pm 4.2 \mathrm{~A}$ \\
\hline \multirow{3}{*}{ Orelia } & 0 & $0.89 \pm 0.2 \mathrm{~F}$ & $0.77 \pm 0.5 \mathrm{~F}$ & $0.8 \pm 0.1 \mathrm{~F}$ & $0.89 \pm 0.2 \mathrm{~F}$ & $0.77 \pm 0.5 \mathrm{~F}$ & $0.8 \pm 0.1 \mathrm{~F}$ & $0 \pm 0 \mathrm{~A}$ & $0 \pm 0 \mathrm{~A}$ \\
\hline & 675 & $574 \pm 19.9 \mathrm{CD}$ & $427 \pm 7.3 \mathrm{DE}$ & $389 \pm 48.6 \mathrm{DE}$ & $679 \pm 67.3 \mathrm{BC}$ & $388 \pm 96.9 \mathrm{DE}$ & $277 \pm 76.5 \mathrm{E}$ & $0 \pm 0 \mathrm{~A}$ & $0 \pm 0 \mathrm{~A}$ \\
\hline & 1500 & $1363 \pm 245 \mathrm{~A}$ & $822 \pm 52.2 B$ & $733 \pm 36.6 \mathrm{BC}$ & $1281 \pm 409 \mathrm{~A}$ & $718 \pm 33.8 \mathrm{BC}$ & $664 \pm 32.7 \mathrm{BC}$ & $0 \pm 0 \mathrm{~A}$ & $0 \pm 0 \mathrm{~A}$ \\
\hline
\end{tabular}

Note: Values followed by the same letter, within the same source of variation, are not significantly different at $\mathrm{P}<0.05$

\section{Effect of labile As on soil germination}

Seedling germination was affected by all the three factors: soil type, amendment rate, and soil As source (Table 2). Fig. 1 shows the germination pattern in the four soils at two different concentrations of sodium arsenate and DMA (Fig. 1 a, b). The four unamended soils had $\geq 90 \%$ germination rate. For sodium arsenate and DMA-treated Immokalee soils (Fig. 1), germination rate ranged between 89 and $97 \%$. This was expected since total As content in Immokalee decreased from $675 \mathrm{mg} \mathrm{As} / \mathrm{kg}$ to $<83$ and $<30 \mathrm{mg}$ As/ $\mathrm{kg}$ in the case of inorganic and organic arsenicalamended soils, respectively. For Pahokee Muck, germination ranged between $74 \%$ and $92 \%$. This could be attributed to the high amount of native $\mathrm{Fe} /$ Al oxyhydroxide present in Pahokee Muck, which resulted in less plant-available As. After leaching, the labile As form for Pahokee Muck was $<25 \%$ of the total applied As for both pesticides.

This small amount of available As together with the high organic matter contributed to the high germination observed in Pahokee Muck. However, for Orelia, the total As content was still high after leaching, and $>50 \%$ of this total As content was in the labile form. Labile As concentration ranged between $427 \pm 7$ to $822 \pm 52$ and $388 \pm 97$ to $718 \pm 33.8$ for sodium arsenate and DMA-treated soils, respectively (Table 3 ). Moreover, Orelia had the highest clay content among the four soils. Due to the high clay percentage, roots did not have appropriate anchorage, which lead to root inhibition. These two factors collectively affected germination, resulting in $58 \%-40 \%$ and $16 \%-22 \%$ germination at 675 and $1500 \mathrm{mg} \mathrm{As} / \mathrm{kg}$ for both pesticides. A decrease in percentage of germination with an increase in As concentration is similar to the trend observed by Abedin and Meharg (2002a) and Liu et al. (2005). In Millhopper spiked with DMA, $\geq 87 \%$ germination was observed. For the sodium arsenate-treated soils, germination decreased to $58 \%$ and $39 \%$ at the lower (675) and higher (1500) treatment rates, respectively. This difference in germination between the two pesticides can be attributed to DMA being less toxic than the sodium arsenate (Pongtraz, 1998). Studies have also shown that the order of arsenic availability to rice (Oryza sativa L.) was as follows: DMA $<$ As (V) $<$ MMA $<$ As (III) (Marin et al., 1992). The high $\mathrm{P}$ content in Millhopper might have increased the available As. This increased availability and low phytoavailability of DMA, compared to sodium arsenate, affected germination in Millhopper. 

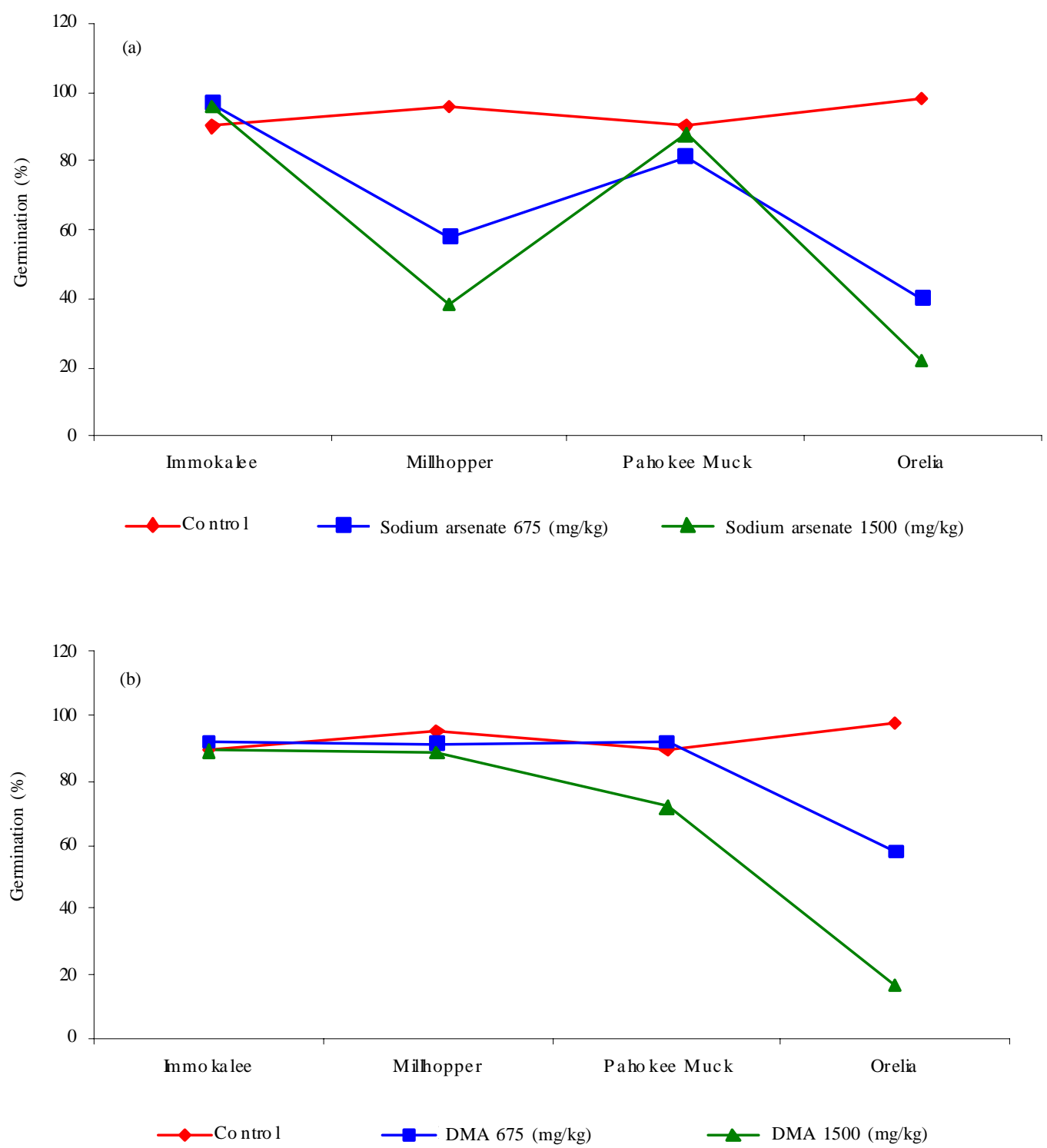

Fig. 1: Effect of labile arsenic on seed germination grown on Immokalee, Millhopper, Pahokee Muck and Orelia amended at two different concentrations of sodium arsenate a) and DMA, b): $675 \mathrm{mg} \mathrm{As} / \mathrm{kg}$ soil and $1500 \mathrm{mg} \mathrm{As} / \mathrm{kg}$ soil

Effect of labile arsenic on plant biomass, shoot height and root length

Decreased root and shoot lengths have been reported in response to toxic metals (Kabata-Pendias and Pendias, 1984). Reduced root growth in response to As exposure has been reported by a number of investigators (Meharg and Macnair, 1992; Kapustka et al., 1995; Sneller et al., 1999; 2000; Hartley-Whitaker et al., 2001). A reduction in plant growth as represented by root, shoot and total (shoot + root) dry weight exposed to DMA has also been observed (Marin et al., 1993a; Carbonell et al., 1998; ). Other researchers have also observed toxicity symptoms resulting from root application of DMA in beans (Sachs and and Michael, 1971), soybeans and radishes (Woolson and Isensee, 1981). Similar results were also obtained and viewed in this study. Soil type, treatment rates, and As source significantly $(\mathrm{P}<0.05)$ affected plant height (shoot 
height and root length) (Table 2). For unamended soils, the shoot height and the root length ranged from 34.5 to $186 \mathrm{~mm}$ and 5.6 to $58.5 \mathrm{~mm}$, respectively (Table 3). Soil spiking with either sodium arsenate or DMA resulted in reduced shoot length. For soils treated with sodium arsenate, the shoot height and root length ranged from 13 to $84.5 \mathrm{~mm}$ and 2.9 to $24.3 \mathrm{~mm}$, respectively. With the exception of Millhopper, no significant difference $(\mathrm{P}>0.05)$ was observed in the shoot length for plants grown in the two different arsenical pesticides. Similar trends were observed for the root length, except for Immokalee and Millhopper at the higher pesticide treatment rates. However, a significant difference $(\mathrm{P}<0.05)$ was present in the shoot and root length within a particular soil between two different concentrations (Table 3). Increased As concentration resulted in reduced shoot and root length for every soil except for Orelia. The results in this study were similar to those of Abedin and Meharg (2002a) and Liu et al. (2005), who found significant decreases in root and shoot height with increasing As concentrations.

Plant biomass varied with soils as well as amendment rates (Table 2). Biomass showed a similar decreasing trend (reduced biomass for amended soils compared to the control). Increased concentration (for both pesticides) resulted in significant decrease in biomass for all the soils (Table 3). Identical results were reported from studies with DMA in wetland vegetation (Carbonell et al., 1998). However, there was no significant difference $(\mathrm{P}<0.05)$ in plant biomass with respect to the As source (Table 3). For Millhopper amended with sodium arsenate at $1500 \mathrm{mg} \mathrm{As} / \mathrm{kg}$ and Orelia, seedling germination did not result in plant growth. Plant roots being the first point of contact with As, increasing As concentration results in significant reduction of root length (Abedin and Meharg, 2002a). Marin et al. (1993a) and Carbonell et al. (1998) also monitored significantly reduced plant growth with increasing DMA concentrations in their solutions.

\section{Effect of labile arsenic on plant uptake}

Soil-type, plant species, nutrient status and environmental stress affect the phytotoxicity at a given soil-arsenic level (Woolson, 1983). Table 3 shows the plant As uptake, which varied with As concentration and soil type. However, no significant difference in As uptake with respect to As source (Table 2) was observed. As uptake was observed in all the plants except for those grown in Orelia and Millhopper amended with sodium arsenate at $1500 \mathrm{mg}$ As/kg. Poor seed germination in Millhopper spiked with Sodium arsenate at $1500 \mathrm{mg} \mathrm{As} / \mathrm{kg}$ resulted in no plant growth. For both pesticides, plant As uptake was highest in Immokalee spiked with $675 \mathrm{mg}$ As/kg. Plant uptake ranged from $133 \pm 48.5$ to $243 \pm 108 \mathrm{mg} \mathrm{As} / \mathrm{kg}$ dry wt of the plant (Table 3). A review of phytotoxic levels of soil As found that inorganic As is five times more toxic in sands than in clay soils (Sheppard, 1992). However, in Immokalee which is a sandy soil with low extractable $\mathrm{Fe} / \mathrm{Al}$ and, hence, a very low As retention capacity; the majority of the As had become part of the leachate water. The total As concentration in Immokalee soil after leaching was 112 and $145 \mathrm{mg}$ of As/kg soil for inorganic arsenical pesticide-treated soils. For the organic arsenical, total As dropped to 33 and $38 \mathrm{mg}$ As/kg from 675 and $1500 \mathrm{mg}$ As/kg respectively. Several workers have indicated that As leaching may be a significant factor in reducing the As toxicity of surface soils (Walsh and Keeney, 1975). Moreover, Woolson and Kearney (1973) observed that DMA does not readily bind to soil, and is expected to leach more than inorganic As. As a result, plant growth was observed in Immokalee resulting in As uptake, though the amount was minimal.

For the other two soils, Millhopper and Pahokee Muck, As uptake ranged from $18.3 \pm 2.9$ to $67.7 \pm 3.7$ mg As/kg dry wt of the plant. However, As uptake was low compared to Immokalee soil for both pesticides. This observation coincides with reports that plant uptake of As is usually low on clays and slits, and high on sands and sandy loams (O’Neill, 1995; Woolson, 1973). Most of the As in Pahokee Muck and Millhopper was in the Fe/Al-bound form (data not shown here), which is unavailable for plant uptake and therefore less toxic. High organic matter may have also favored plant growth in the case of Pahokee Muck. Increased As uptake with increased As concentration was observed for Millhopper spiked with DMA and Pahokee Muck amended with both pesticides. The results of this present study were in agreement with previous studies by Marin et al. (1993a) and Carbonell et al .(1998), where As uptake and concentrations in shoots and roots increased as a result of increased DMA concentrations. In contrast, plant As uptake for Immokalee decreased with higher concentrations, which likely resulted in phytotoxic levels and therefore less uptake. Arsenic phytotoxicity increases more in sands than in clay soils 
(Sheppard, 1992). Poor seed germination in the case of Orelia resulted in no plant growth at both amendment rates for both the inorganic and organic pesticides. For Orelia amended with DMA, labile fraction was still $>50 \%$ (388 \pm 97 and $277 \pm 77 \mathrm{mg} / \mathrm{kg}$ for 675 and $1500 \mathrm{mg}$ As/kg respectively) even after leaching. Similar was the case with sodium arsenate. This highly available concentration was phytotoxic enough to result in poor germination, thereby affecting seedling growth.

Relationship between labile As and biomass, root, shoot length, plant As uptake and germination

Table 4 shows the relationship between germination, root and shoot length, biomass, plant As uptake and labile or plant-available As for soils amended with sodium arsenate. A significant negative correlation was obtained between labile As and root length, shoot height, biomass, germination and plant As uptake. This correlation was expected given the data presented in Table 3 and Fig. 1a. Negative correlations further corroborate the observation reported in Table 3. Various studies have reported a decrease in root and shoot length with an increase in As concentration. When the As level increases, the chances of a phytotoxic response by the desired crop also increases (Walsh and Keeney, 1975). Similarly, it was observed that increased As concentration resulted in decreased biomass and root and shoot height. A negative correlation $(r=-0.34)$ was observed between germination and labile As, which suggests that increases in the labile form will decrease the percentage of germination. However, more than 80 \% germination was found except in the case of Millhopper and Orelia soils (Fig. 1a). As a result, an insignificant relationship was witnessed between the two. Similar correlation trends were reported for soils with organic arsenical pesticide (Table 5 and Fig. 1b). In soils amended with DMA, however, a significant relationship was observed between germination and labile As.

Total As in soil, water and plants after 6 months of soil equilibration

Fig. 2 shows the distribution of As in the soil and leachate water of soils amended with sodium arsenate at two rates: $675 \mathrm{mg}$ As/kg and $1500 \mathrm{mg} \mathrm{As/}$ $\mathrm{kg}$. Distribution depended on the soil properties. In soil, As is mainly associated with Fe oxides and hydroxides (Fassbender, 1974; Akins and Lewis, 1976; Hale et al., 1997). Immokalee is a sandy soil with low extractable $\mathrm{Fe} / \mathrm{Al}$ and has very low As retention capacity. This is reflected in the mass balance profile for Immokalee. For both amendment rates, the majority of the As was present in the leachate, leaving small residues in the soil (Fig. 2a). A significant amount of As was retained in the surface soil, and to a similar degree in the leachate water for Millhopper (Fig. 2b). Sorption of dissolved As on soil is controlled by Fe oxides (Elkhatib et al., 1984; Fordham and Norrish, 1983) and increases with Fe and Al oxide content (Jacobs et al., 1970). Because Millhopper has a high Fe/Al content, it has a high As retention capacity compared to that of Immokalee, resulting in equal distribution of As in the soil and leachate (Fig. 2b). For Pahokee Muck and Orelia, soil proved to be the major pool for As. A small quantity of As was part of the leachate water. Fe oxides and clay are the major As (V) adsorption sites in soil (Smith et al., 1998; Mahimairaja et al., 2005). Thus, the high oxalate-extractable Fe/Al present natively

Table 4: Pearson correlation coefficients for labile arsenic and different vegetative response: Germination, biomass, shoot length, root length and plant arsenic uptake in rice grown in all the four soils treated with sodium arsenate

\begin{tabular}{|c|c|c|c|c|c|c|c|}
\hline & $\begin{array}{c}\text { Germination } \\
\text { (\%) }\end{array}$ & $\begin{array}{l}\text { Biomass } \\
\text { (gm) }\end{array}$ & $\begin{array}{c}\text { shoot } \\
\text { length } \\
(\mathrm{mm})\end{array}$ & $\begin{array}{c}\text { root } \\
\text { length } \\
(\mathrm{mm})\end{array}$ & $\begin{array}{l}\text { As plant } \\
\text { uptake } \\
\text { (mg/kg } \\
\text { dry wt) }\end{array}$ & $\begin{array}{l}\text { Total As (mid) } \\
\text { (mg/kg) }\end{array}$ & $\begin{array}{l}\text { Labile As (mid) } \\
\text { (mg/kg) }\end{array}$ \\
\hline Germination (\%) & 1.00 & 0.73 & 0.57 & 0.59 & 0.68 & -0.48 & -0.34 \\
\hline Biomass (gm) & & 1.00 & 0.94 & 0.96 & 0.86 & -0.75 & $-0.64 * * *$ \\
\hline Shoot length (mm) & & & 1.00 & 0.99 & 0.70 & -0.72 & $-0.66 * * *$ \\
\hline Root length (mm) & & & & 1.00 & 0.75 & -0.75 & $-0.68 * * *$ \\
\hline $\begin{array}{l}\text { As plant uptake } \\
\text { (mg/kg.dry wt) }\end{array}$ & & & & & 1.00 & -0.60 & $-0.45 *$ \\
\hline Total As (mid) (mg/kg) & & & & & & 1.00 & $0.95 * * *$ \\
\hline Labile As (mid) (mg/kg) & & & & & & & 1.00 \\
\hline
\end{tabular}

Note: * and *** represent the $\mathrm{F}$ values with $\mathrm{P}$ levels of $<0.05$ and $<0.0001$ respectively 

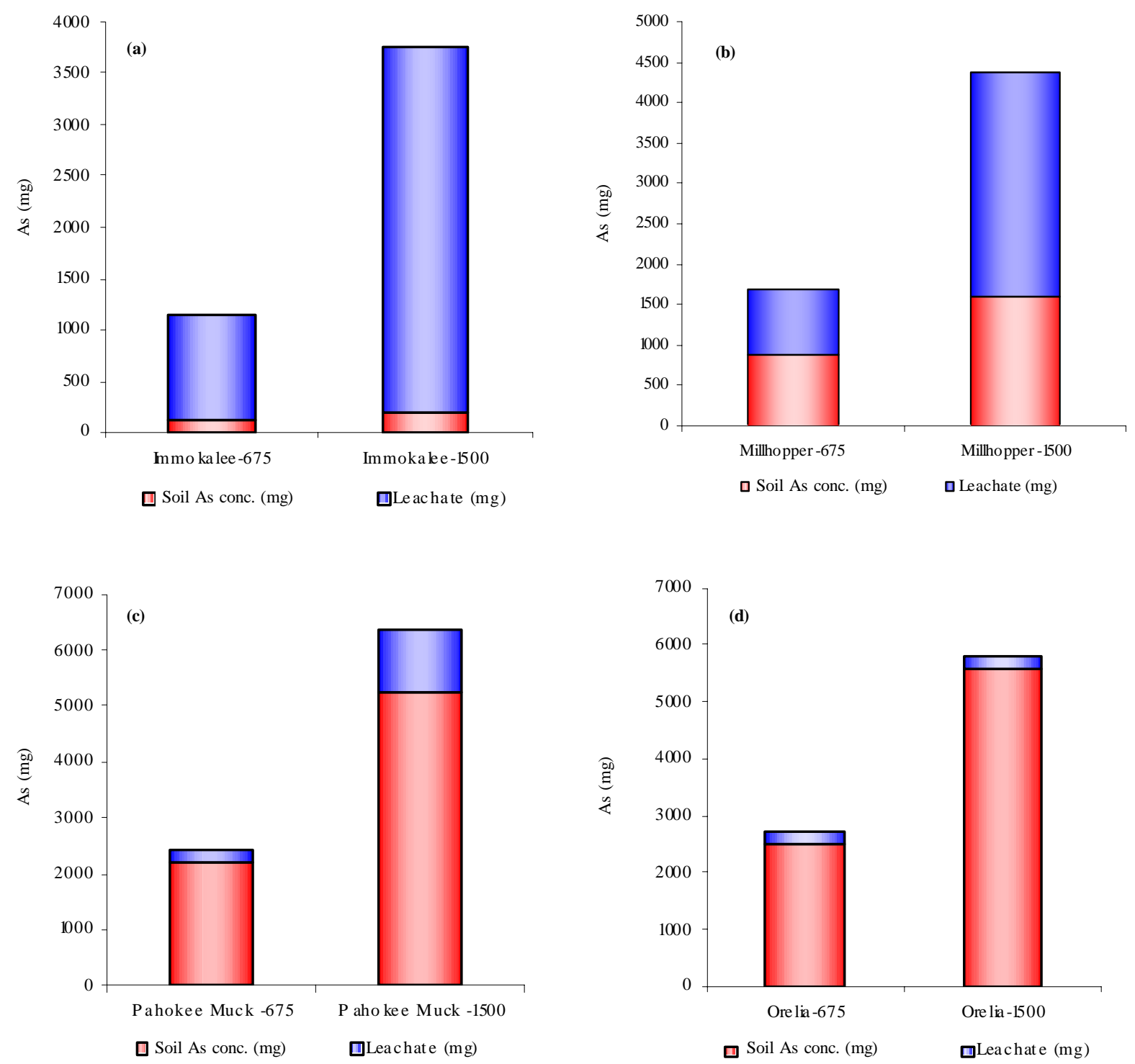

Fig. 2: Mass Balance of As (sodium arsenate) in a) Immokalee, b) Millhopper, c) Pahokee Muck and d) Orelia. Plant As concentration for Immokalee, Millhopper and Pahokee Muck was minimal

in Pahokee Muck and the high clay content in Orelia explain the unequal distribution of As in the two pools: soil and leachate water (Fig. 2c, d). Plant As uptake was minimal for Immokalee soil (data off-scale in Fig. 2a). The majority of As leached downwards, resulting in a decreased total concentration of As. The amount of As taken up by the rice plants, was negligible compared to the amount of As present in the soil and the leachate. For Pahokee Muck and Millhopper soils, plant As uptake was less compared to Immokalee. Most of the As present in Millhopper and Pahokee Muck was associated with $\mathrm{Fe} / \mathrm{Al}$ oxyhydrooxides (data not shown here) and was thus unavailable and less toxic. Moreover, high organic matter in Pahokee Muck favored germination and subsequent plant growth. Orelia witnessed no plant growth. In all the soils, As present in the plant was negligible compared to the amount present in the soil and leachate water. 
Distribution of As in soil and leachate water for soils amended with DMA at $675 \mathrm{mg}$ As/kg and $1500 \mathrm{mg}$ As/ $\mathrm{kg}$ is shown in Fig. 3. Leaching affected the soil As distribution in Immokalee. Most of the As was extracted
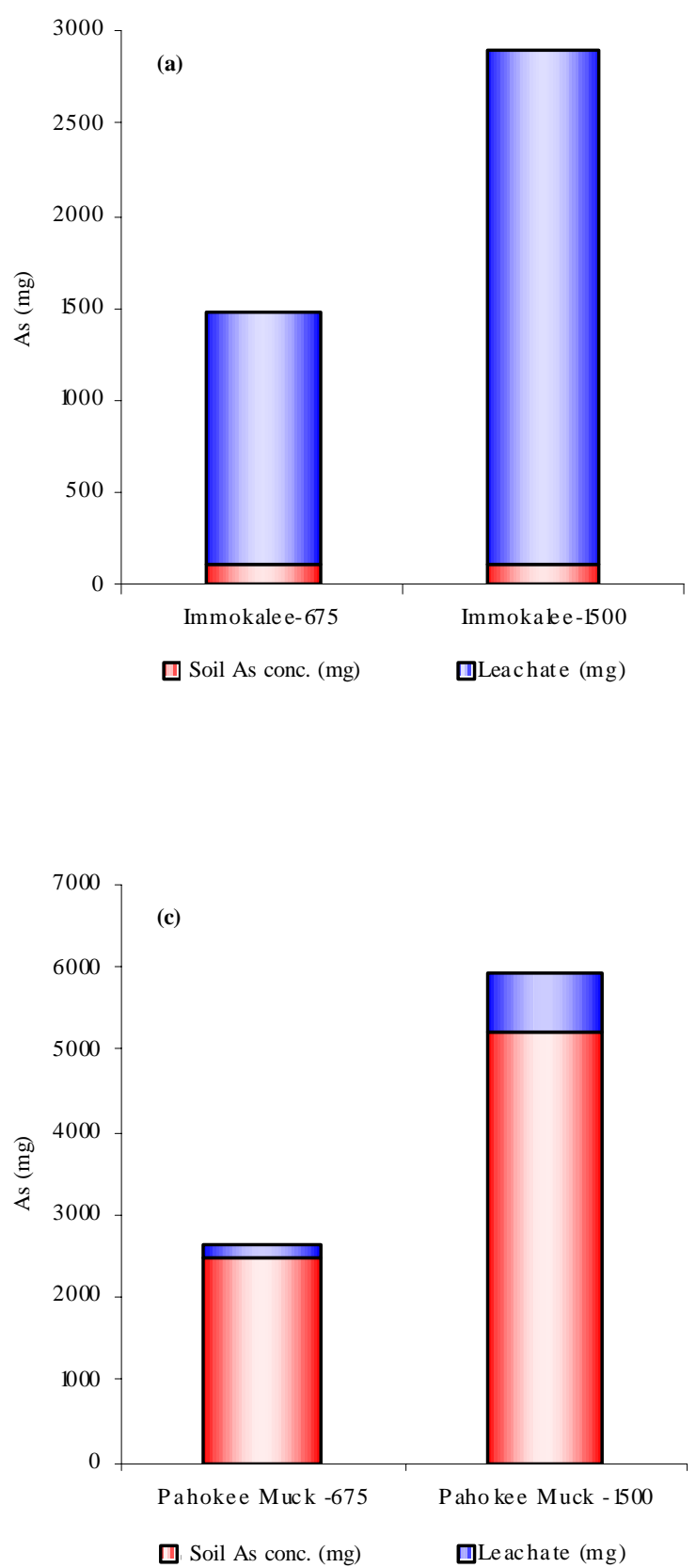

from the leachate, which was similar to soils with inorganic arsenicals. The other three soils (Millhopper, Pahokee Muck, and Orelia) followed retention of total As similar to those spiked with sodium arsenate.
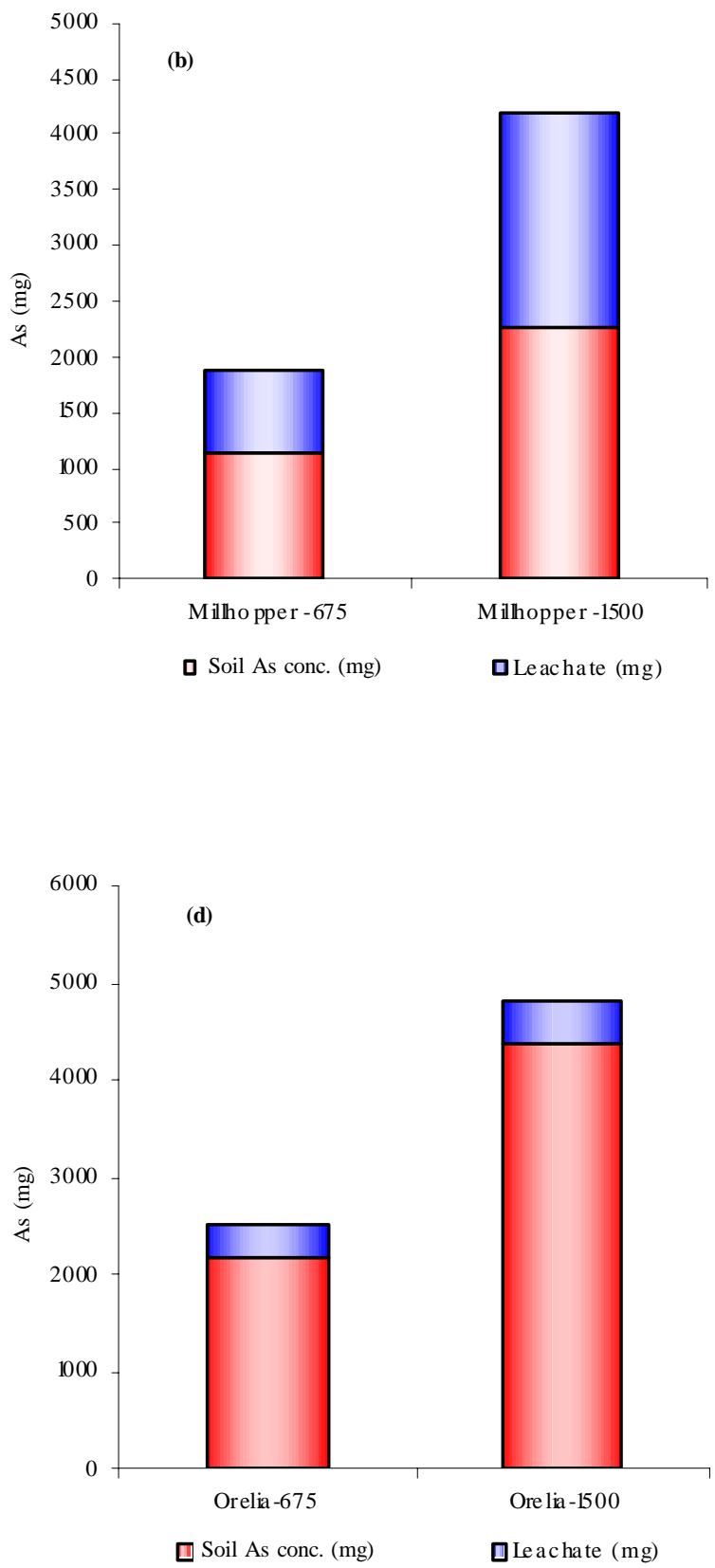

Fig. 3: Mass Balance of As (DMA) in a) Immokalee, b) Millhopper, c) Pahokee Muck and d) Orelia. Plant As concentration for Immokalee, Millhopper and Pahokee Muck was minimal 
Int. J. Environ. Sci. Tech., 8 (3), 445-460, Summer 2011

Table 5: Pearson correlation coefficients for labile As and different vegetative response: Germination, biomass, shoot length, root length and plant As uptake in rice grown in all four soils treated with DMA

\begin{tabular}{|c|c|c|c|c|c|c|c|}
\hline & $\begin{array}{c}\text { Germination } \\
(\%)\end{array}$ & $\begin{array}{l}\text { Biomass } \\
\text { (gm) }\end{array}$ & $\begin{array}{c}\text { Shoot } \\
\text { length } \\
(\mathrm{mm})\end{array}$ & $\begin{array}{l}\text { Root length } \\
(\mathrm{mm})\end{array}$ & $\begin{array}{l}\text { As plant uptake } \\
\text { (mg/kg dry wt) }\end{array}$ & $\begin{array}{l}\text { Total As (mid) } \\
\text { (mg/ kg) }\end{array}$ & $\begin{array}{c}\text { Labile As } \\
\text { (mid) } \\
\text { (mg/kg) }\end{array}$ \\
\hline$\overline{\text { Germination (\%) }}$ & 1.00 & 0.68 & 0.75 & 0.72 & 0.54 & -0.47 & $-0.89 * * *$ \\
\hline Biomass (gm) & & 1.00 & 0.84 & 0.91 & 0.82 & -0.78 & $-0.78 * * *$ \\
\hline Shoot length (mm) & & & 1.00 & 0.96 & 0.67 & -0.65 & $-0.67 * * *$ \\
\hline Root length (mm) & & & & 1.00 & 0.72 & -0.72 & $-0.71 * * *$ \\
\hline $\begin{array}{l}\text { As plant uptake } \\
\text { (mg/kg dry wt) }\end{array}$ & & & & & 1.00 & -0.61 & $-0.62 * *$ \\
\hline Total As (mid) (mg/kg) & & & & & & 1.00 & $0.71^{* * *}$ \\
\hline Labile As (mid) (mg/kg) & & & & & & & 1.00 \\
\hline
\end{tabular}

Note: $* *$ and $* * *$ represent the $\mathrm{F}$ values with $\mathrm{P}$ levels of $<0.001$ and $<0.0001$ respectively

\section{CONCLUSION}

Comparative studies on plant responses when exposed to soils highly contaminated with inorganic and organic arsenical pesticide are limited. Vegetative response end points such as root length, shoot height, root and shoot biomass and total biomass (root + shoot) are widely used to study metal resistance (Abedin and Meharg, 2002a). This study evaluated the relationship between soil properties and plantavailable As, and their effect on rice. The amount of plant-available fraction of As was affected by the differences in soil physiochemical properties. Both sodium arsenate and DMA pesticides behaved in an identical way with respect to soil As retention, affecting phytotoxicity. High levels of As was found in the leachate fraction in Immokalee soil, which resulted in much lower levels of As in the surface soil. However, for Millhopper soil, As was equally distributed between the soil and leachate water. For Pahokee Muck and Orelia, soil proved to be the major As pool. Labile form varied with the soil type as source and amendment rate. Seedling germination was also affected by all three factors: soil type, amendment rate, and soil As source. Soil As source did not affect shoot length $(\mathrm{P}>0.05)$. In contrast, it affected root length in Immokalee and Millhopper amended at 675 and $1500 \mathrm{mg} \mathrm{As} / \mathrm{kg}$. A similar trend was observed for As uptake. Plant As uptake varied only with As concentration and soil type. Soil amendments affected biomass; reduced biomass for contaminated soils compared to untreated soils. Plant biomass was not affected by the As source. Reduced shoot and root length was also observed with increased As concentration for all the treatments.

\section{ACKNOWLEDGEMENTS}

The authors would like to thank the US EPA-STAR program (EPA Grant Number: R830842) for funding this study.

\section{REFERENCES}

Abedin, M. J.; Cottep-Howells, J.; Meharg, A. A., (2002b). Arsenic uptake and accumulation in rice (Oryza sativa L.) irrigated with contaminated water. Plant and Soil., 240, 311319 (9 pages).

Abedin, M. J.; Meharg, A. A., (2002a). Relative toxicity of arsenite and arsenate on germination and early seedling growth of rice (Oryza sativa L.). Plant soil., 243 (1), 57-66 (10 pages).

Abedin, M. J.; Cresser, M. S.; Meharg, A. A.; Feldmann, J.; Cotter-Howells, J., (2002c). Arsenic accumulation and metabolism in rice. Environ. Sci. Tech., 36 (5), 962-968 (7 pages).

Adriano, D. C., (2001). Trace elements in terrestrial environments: Biogeochemistry, bioaccessibility and the risk

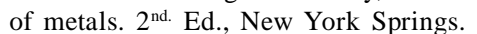

Akins, M. B.; Lewis, J. R., (1976). Chemical distribution and gaseous evolution of arsenic-74 added to soils as DSMA74As. Soil Sci. Soc. Am., 40, 655-658 (4 pages).

Alam, M. B.; Sattar, M. A., (2000). Assessment of arsenic contamination in soils and waters in some areas of Bangladesh. Water Sci. Tech. 42 (7-8), 185-193 (9 pages).

Baker, R. S.; Barrentine, W. L.; Bowman, D. H.; Hawthorne, W. L.; Pettiet, J. V., (1986). Crop response and arsenic uptake following soil incorporation of MSMA. Weed Science., 24 (3), 322-326 (5 pages).

Belluck, D. A.; Benjamin, S. L.; Baveye, P.; Sampson, J.; Johnson, V., (2003). Widespread arsenic contamination of soils in residential areas and public spaces: An emerging regulatory or medical crisis? Int. J. Toxicol., 22 (6), 109128 (20 pages).

Carbonell, A. A.; Aarabi, M. A.; DeLaune, R. D.; Gambrell, R. P.; Patrick Jr, W. H., (1998). Arsenic in wetland vegetation: Availability, phytotoxicity, uptake and effects on plant growth and nutrition. Sci. Total Environ., 217 (3), 189-199 (11 pages). 
Carbonell-Barachina, A. A.; Burlo-Carbonell, F.; MataixBeneyto. J., (1995). Arsenic uptake, distribution and accumulation in tomato plants: effect of arsenic on plant growth and yield. J. Plant Nutri., 18 (6), 1237-1250 (14 pages).

Chen, M.; Ma, L. Q.; Harri, W. G., (1999). Baseline concentrations of 15 trace elements in Florida surface soils. J. Environ. Qual., 28 (4), 1173-1181 (9 pages).

Chungao, C.; Zihui, L., (1988). Chemical speciation of arsenic in water, suspended solids and sediment of Xiangjiang river. China. Sci. Total Environ., 77 (1), 69-82 (14 pages).

Cullen, W. R.; Reimer, K. J., (1989). Arsenic speciation in the environment. Chem. Rev., 89 (4), 713-764 (52 pages).

Datta, R.; Sarkar, D., (2005). Consideration of soil properties in assessment of human health risk from exposure to arsenic-enriched soils. Integr. Environ. Assess. Manag., 1 (1), 55-59 (5 pages).

Datta, R.; Sarkar, D., (2004). Arsenic geochemistry in three soils contaminated with sodium arsenite pesticide: An incubation study. Environ. Geosci., 11 (2), 53-63 (11 pages).

Dickens, R.; Hiltbold. AR., (1967). Movement and persistence of methanearsenate in soils. Weeds, 15 (4), 299-304 (6 pages).

Elkhatib, E. A.; Bennett, O. L.; Wright. R. J., (1984). Arsenite sorption and desorption in soils. Soil Sci. Soc. Am. J., 48, 1025-1030 (6 pages).

Fassbender, H. W., (1974). Content, forms and fixation in forest soils of arsenate in comparison with phosphate. Z. Pflanzenernaehr. Deung. Bodenkd. 137, 188-203 (16 pages).

Feng, X. D.; Dang, Z.; Huang, W. L.; Yang, C., (2009). Chemical speciation of fine particle bound trace metals. Int. J. Environ. Sci. Tech., 6 (3), 337-346 (10 pages)

Fordham, A. W.; Norrish, K., (1983). The nature of soil particles particularly those reacting with arsenate in a series of chemically treated samples. Aust. J. Soil Res., 21 (4), $455-477$ (23 pages).

Frans, R.; Horton. D.; Burdette, L., (1988). Influence of MSMA on straighthead, arsenic uptake and growth response in rice (Oryza sativa). Fayetteville, University of Arkansas.

Garcia-Manyes, S.; Jiménez, G.; Padró, A.; Rubio, R; Rauret, G., (2002). Arsenic speciation in contaminated soils. Talanta, 58 (1), 97-109 (13 pages).

Hale, J. R.; Foos, A.; Zubrow, J. S; Cook. J., (1997). Better characterization of arsenic and chromium in soils: A fieldscale example. J. Soil Contam., 6 (4), 371-389 (19 pages).

Han, F. X.; Kingery, W. L.; Selim, H. M.; Gerard, P. D.; Cox, M. S.; Oldham, J. L., (2004). Arsenic solubility and distribution in poultry waste and long term amended soil. Sci. Total Environ., 320 (1), 51-61 (11 pages).

Hartley-whitaker, J.; Ainsworth, G.; Mearg. A. A., (2001). Copper- and arsenate-induced oxidative stress in Holcus Lanatus $L$. clones with differential sensitivity. Plant Cell Environ., 24 (7), 713-722 (10 pages).

Jahiruddin, M. M. R.; Islam, A. L.; Shah, S.; Islam, M.; Ghani, A.; (2004). Effects of arsenic contamination on yield and arsenic accumulation in crops. Shah M. (Ed.). Workshop on Arsenic in the Water-Soil-Crop Systems, BRRI, Gazipur, Bangladesh, 147, 39-52.
Jacobs, L. W.; Keeney, D. R.; Walsh, L. M., (1970) Arsenic residue toxicity to vegetable crops grown on plainfield sand. Agron. J., 62 (5), 588-591 (4 pages).

Johnson, L. R.; Hiltbold, A. E., (1969). Arsenic content of soil and crops following use of methane arsenate herbicides. Soil Sci. Soc. Am. Proc., 33, 279-282 (4 pages).

Johnston, S. E.; Barnard, W. M., (1979). Comparative effectiveness of fourteen solutions for extracting arsenic from four western New York soils. Soil Sci. Soc. Am. J., 43, 304-308 (5 pages).

Kabata-Pendias, A.; Pendias. H., (1984). Trace elements in soils and plants, CRC Press, Inc, Boca Raton , Florida, USA,

Kang, L. J.; Li, X. D.; Liu, J. H.; Zhang, X., (1996). The effect of arsenic on the growth of rice and residues in a loam paddy soil. J. Jilin Agri. Univ., 18, 58-61 (3 pages).

Kapustka, L. A.; Lipton, J.; Galbraith, H.; Cacela, D.; Lejeune. K., (1995). Metal and arsenic impacts to soils, vegetation communities and wildlife habitat in southwest Montana uplands contaminated by smelter emissions: II. Laboratory phytotoxicity studies. Environ. Toxicol. Chem., 14 (110), 1905-1912 (8 pages).

Liao, X. Y.; Chen, T. B.; Xie, H.; Liu, Y. R., (2005). Soil As contamination and its risk assessment in areas near the industrial districts of Chenzhou city, Southern China. Environ. Int., 31 (6), 791-798 (8 pages).

Liebig, G. F., (1966). Arsenic. Champan, H. D. (Ed.), Diagnostic Criteria for Plants and Soils University of California Press, Riverside., CA.

Liu, X.; Zhang, S.; Shan, X.; Zhu. Y., (2005). Toxicity of arsenate and arsenite on germination, seedling growth and amylolytic activity of wheat. Chemosphere., 61 (2), 293301 (9 pages).

Livesey, N. T.; Huang. P. M., (1981). Adsorption of arsenate by soils and its relation to selected chemical properties and anions. Soil Sci., 131 (2), 88-94 (7 pages).

Li, R. Y.; Stroud, J. L.; Ma, J. F.; McGrath, S. P.; Zhao, F. J., (2009). Mitigation of arsenic accumulation in rice with water management and silicon fertilization. Environ. Sci. Tech., 43 (10), 3778-3783 (5 pages).

MacLean, K. S.; Langille. W. M., (1981). Arsenic in orchard and potato soils and plant tissue. Plant Soil, 61 (3), 413418 (6 pages).

Mahimairaja, S.; Bolan, N. S.; Adriano, D. C.; Robnson. B., (2005). Arsenic contamination and its risk management $n$ complex environmental settings. Ad. Agron., 86, 1-82 (82 pages).

Manning, B. A.; Goldberg. S., (1996). Modeling competitive adsorption of arsenate with phosphate and molybdate on oxide minerals. Soil Sci. Soc. Am. J., 60 (1), 121-131 (11 pages).

Marin, A. R.; Pzeshki, S. R.; Masschelen, P. H.; Choi, H. S., (1993a). Effects of diemthylarsenic acid (DMAA) on growth, tissue arsenic and photosynthesis of rice plants. J. Plant Nutr., 16 (5), 865-880 (15 pages).

Marin, A. R.; Masscheleyn, P. H.; Patrick Jr, W. H., (1992). The influence of chemical form and concentration of arsenic on rice growth and tissue arsenic concentration. Plant Soil., 139 (2), 175-183 (9 pages).

Marin, A. R.; Masscheleyn, P. H.; Patrick Jr, W. H., (1993b). Soil redox-pH stability of arsenic species and its influence 
on arsenic uptake by rice. Plant Soil., 152 (2), 245-253 (9 pages).

Meharg, A. A.; Macnair, M. R.; (1992). Suppression of the High Affinity Phosphate Uptake System: A Mechanism of Arsenate Tolerance in Holcus lanatus L. J. Exp. Bot., 43 (4), 519-524 (6 pages).

Mehlich, A.; (1984). Mehlich No. 3 soil test extractant: A modification of Mehlich No. 2 extractant: Commun soil Sci. Plant Anal., 15, 1409-1416 (8 pages).

Murphy, E. A.; Aucott, M., (1998). An assessment of the amounts of arsenical pesticides used historically in a geographically area. Sci. Total Environ., 218 (2-3), 89-101 (13 pages).

NAS, (1977). Arsenic. National Academy of Sciences. The National Research Council,Washington, DC.

NRC, (1977). Arsenic in medical and biological effects of environmental pollutants, National Academy of Sciences, Washington, DC, National Research Council.

O’Neill, P., (1995). Arsenic. Alloway, B. J., (Eds). Heavy metals in soils. Blackie Academic and Professional.

Odanaka, Y.; Tsuchiya, N.; Matano, O.; Goto, S., (1987). Absorption, translocation and metabolism of the arsenical fungicides, iron methanearsonate and ammonium iron methanearsonate, in rice plants. J. Pestic. Sci., 12 (2), 199208 (10 pages).

Onken, B. M.; Adriano, D. C., (1997). Arsenic availability in soil with time under saturated and unsaturated conditions. Soil Sci Soc Am J., 61, 746-752 (7 pages).

Oscarson, D. W.; Huang, P. M.; Defosse, C.; Herbillon. A., (1981). Oxidative power of $\mathrm{Mn}$ (IV) and Fe (III) oxides with respect to As (III) in terrestrial and aquatic environments. Nature, 291, 50-51 (2 pages).

Pierce, M. L.; Moore, C. B., (1980). Adsorption of arsenite on amorphous iron hydroxide from dilute aqueous solution. Environ. Sci. Tech., 14 (2), 214-216 (3 pages).

Pongratz, R., (1998). Arsenic speciation in environmental samples of contaminated soil. Sci. Total Environ., 224 (13), 133-141 (9 pages).

Reeds, J. F.; Sturgis, M. B., (1936). Toxicity from arsenic compounds to rice on flooded soils. J. Am. Soc. Agron., 28, 432-436 (5 pages).

Sachs, R. M.; Michael, J. L., (1971). Comparative phytotoxicity among four arsenical herbicides. Weed Sci., 19 (5), 558-564 (7 pages).

Saha, G. C.; Ali, M. A.; (2007). Dynamics of arsenic in agricultural soils irrigated with arsenic contaminated groundwater in Bangladesh. Sci. Total Environ., 379 (2-3), 180-189 (10 pages).

Sall, J.; Creighton, L.; Lehman, A., (2005). JMP start statistics. Third edition. Cary, NC: SAS Institute and Pacific Grove, CA.

Sarkar, D.; Datta, R.; Sharma. S., (2005). Fate and bioavailability of arsenic in organoarsenical pesticide-applied soils. Part-I: Incubation study. Chemosphere, 60 (2), 188-195 (8 pages).

Schweizer, E. E., (1967). Toxicity of DSMA soil residues to cotton and rotational crops. Weeds, 15 (1), $72-76$ (5 pages).

Sckerl, M. M.; Frans, R. E., (1969). Translocation and metabolism of MMA-1\#C in johnsongrass and Cotton. Weed Sci., 17 (4), 421-427 (7 pages).

Sheppard, S. C., (1992). Summary of phytotoxic levels of soil arsenic. Water Air Soil Pollut., 64 (3-4), 539-550 (12 pages).
Smith, E.; Naidu, R.; Alston, A. M., (1998). Arsenic in soil environment: A review. Adv. Agron., 64, 149-195 (47 pages).

Sneller, E. F. C.; Van Heerwaaden, L. M.; Kraaijeveld-Smit, F. J. L.; Ten Bookum, W. M.; Koevoetes, P. L. M.; Schat, H.; Verkleij, J. A. C., (1999). Toxicity of arsenate in Silene vulgaris, accumulation and degradation of arsenate-induced phytochelatins. New Phytol., 144 (2), 223-232 (10 pages).

Sneller, E. F. C.; Van Heerwaaden, L. M.; Schat, H.; Verkleij, J. A. C., (2000). Toxicity, metal uptake, and accumulation of phytochelatins in Silene vulgaris exposed to mixtures o cadmium and arsenate. Environ. Toxicol. Chem., 19 (12), 2982-2986 (5 pages).

Sparks, D. L., (1996). Methods of Soil Analysis: Part 3, Chemical Methods. Madison, Wis.: Soil Science Society of America: American Society of Agronomy.

Turpeinen, R.; Pantsar-Kallio, M.; Häggblom, M.; Kairesalo, T., (1999). Influence of microbes on the mobilization, toxicity and biomethylation of arsenic in soil. Sci. Total Environ., 236 (1-3), 173-180 (8 pages).

Ullah, S. M., (1998). Arsenic contamination of groundwater and irrigated soils of Bangladesh. IN Abstracts: International Conference on Arsenic Pollution of Ground Water in Bangladesh: causes, effects and remedies. 8-12 February 1998, Dhaka Community Hospital, Dhaka, Bangladesh.

Urík, M.; Littera, P.; Sevc, J.; Koleník, M.; Cernanský, S., (2009). Removal of arsenic (V) from aqueous solutions using chemically modified sawdust of spruce (Picea abies): Kinetics and isotherm studies. Int. J. Environ. Sci. Tech., 6 (3), 451456 (8 pages).

US EPA, (1996). Test methods for evaluating solid waste. SW 846.3d ed. Office of solid waste and emergency response, Washington, DC.

US EPA, (2009). Organic arsenicals; product cancellation order and amendments to terminate uses. Federal Register Environmental Documents. Avaiable at: http://www.epa.gov/ fedrgstr/EPA-PEST/2009/September/Day-30/p23319.htm.

Von Endt, D. W.; Kearney, P. C.; Kaufman, D. D., (1968). Degradation of monosodium acid by soil microorganisms. J. Agric. Food Chem., 16 (1), 17-20 (4 pages).

Walsh, L. M.; Summer, M. E.; Keeney, D. R., (1977). Occurrence and distribution of arsenic in soils and plants. Environ. Health Perspect., 19, 67-71 (5 pages).

Walsh, L. M.; Keeney, D. R., (1975). Behavior and phytotoxicity in inorganic arsenicals in soils, in: Woolson, EA., Arsenical pesticides. American Chemical Society Symposium Series, Washington , DC., 7, 35-52 (18 pages).

Watanabe, F. S.; Olsen, S. R., (1965). Test of an ascorbic acid method for determining phosphorus in water and $\mathrm{NaHCO}_{3}$ extracts from soil. Soil Sci. Am. Proc., 29, 677-678 (2 pages).

Wauchope, R. D., (1975). Fixation of arsenical herbicides, phosphate, and arsenate in alluvial soils. J. Environ. Qual., 4 (3), 355-358 (4 pages).

Woolson, E. A.; Axley, J. H.; Kearney, P. C., (1973). The chemistry and phytotoxicity of arsenic in soils. II. Effcets of time and phosphorus. Soil Sci. Am. Proc., 37 (2), 254259 (6 pages).

Woolson, E. A.; Axley, J. H.; Kearney, P. C., (1971a). Correlation between available soil arsenic, estimated by six methods, and response of corn (Zea mays L.). Soil. Sci. Am. Proc., 35 (1), 101-105 (5 pages). 
Woolson, E. A., (1973). Arsenic phytotoxicity and uptake in six vegetable crops. Weed Sci., 21 (6), 524-527 (4 pages).

Woolson, E. A., (1983). Emissions, cycling and effects of arsenic in soil ecosystems.Fowler, B. A., (Ed). Biological and environmental effects of arsenic. Elsevier Science Publishers, New York, NY.

Woolson, E. A.; Isensee, A. R., (1981). Soil residue accumulation from three applied arsenic sources. Weed Sci., 29 (1), 17-21 (5 pages).
Woolson, E. A.; Kearney, P. C., (1973). Persistence and reactions of ${ }^{14} \mathrm{C}$-cacodylic acid in soils. Environ. Sci. Tech., 7 (1), 47-50 (4 pages).

$\mathrm{Xu}$, J.; Thornton, I., (1985). Arsenic in garden soils and vegetable crops in Cornwall, England: implications for human health. Environ. Geochem. Health, 7 (4), 131-133 (3 pages).

Zhu, Y. G.; Williams, P. N.; Meharg, A. A.; (2008). Exposure to inorganic arsenic from rice: A global health issue. Environ. Pollut., 154 (2), 169-171 (3 pages).

\section{AUTHOR (S) BIOSKETCHES}

Quazi, S., Ph.D., Environmental Geochemistry Laboratory, University of Texas at San Antonio, San Antonio, Texas, USA.

Email: shahida.quazi@gmail.com

Datta, R., Ph.D., Associate Professor, Department of Biological Sciences, Michigan Technological University, Houghton, Michigan, USA. Email: rupdatta@mtu.edu

Sarkar, D., Ph.D., Professor, Department of Earth and Environmental Studies, Montclair State University, Montclair, New Jersey, USA. Email: sarkard@mail.montclair.edu

How to cite this article: (Harvard style)

Quazi, S.; Datta, R.; Sarkar, D., (2011). Effects of soil types and forms of arsenical pesticide on rice growth and development. Int. J. Environ. Sci. Tech., 8 (3), 445-460. 